\title{
Measuring Banking Efficiency during Crisis Period Using Data Envelopment Analysis: Western Balkan Countries Case
}

\author{
Lindita Varesi \\ Banka NBG Albania S.A lindita.varesi@nbgal.groupnbg.gr \\ University of 'Aleksander Moisiu' Durres, Albania varesi.lindita@gmail.com
}

Doi:10.5901/ajis.2015.v4n1p261

\begin{abstract}
The recent years' crisis has affected the Western Balkan economies. The deterioration of macroeconomic indicators was reflected particularly in the banking sector developments as main segment of their financial systems. Referring to the results of previous personal study (Varesi, L., 2014), the banking efficiency, profitability, liquidity, capital adequacy ratios fell during the crisis period compared with that before. The lending remained low despite the continuous reduction of interest rates due to the contraction of these economies. Fluctuations, instability and uncertainties increase the vulnerabilities of financial systems and complicates the banking sector supervision and enforcement of banking regulations. This paper aims to examine the technical efficiency of the banking sector of six Western Balkan countries considered each as a Decision Making Unit, using Data Envelopment Analysis and the intermediation approach according to Avkiran, N.K.,(2006). The paper intends to present differences in the estimated efficiencies to the variables used in representing the size of the banking sector by number of branches, total assets and total loans. The evaluation of efficiencies refers to the year 2007 to 2012. The effects of 2008 crises in the efficiency of banking sector of WB countries are also examined in this comparative study.
\end{abstract}

Keywords: Western Balkans, banking sector, technical efficiency, DEA.

\section{Introduction}

This paper is focused on analyzing the relative, technical efficiency of the banking sector of Western Balkan countries. According to Avkiran, N.K., (2013, p.171) "...Operating efficiently will continue to become increasingly important to organizations of all kinds if we are to maintain the level of prosperity taken for granted in developed countries".

The identification of inefficiencies receives a special attention due to the global economic shocks of the last decade, the continuous changes of the macroeconomic environment, the complexity of banks, firms and organizations operating in economies, full of uncertainties for their stability and development in the long run.

The data and performance of the first quarter of the year 2014 indicates that the euro area "will continue to recover at gradual pace during the rest of 2014 and the year 2015" [Bank of Albania, Financial Stability Report (FSR), 2014H1, p. 21-22]. Referring to the 'Regional benchmarking report of November 2013', countries like Bosnia, Macedonia FYR and Serbia returned in recession during the year 2012 [Financial Stability Benchmarking System, 2013, p.2]. The financial sector vulnerabilities were mainly caused by non paid loans, due to "the re-intensification of de-leveraging within the domestic economies and among parent banks from Europe" 'Regional benchmarking report of November 2013' (FSBS, 2013, p.2). The Western Balkans' banking industry profitability and efficiency ratios during the period 2008-2012 decreased compared with the pre-crisis period according to personal previous study on financial sector size and stability (Varesi, L., 2014).

The banking sector capital adequacy ratios for each of surveyed countries, dropped slightly during the same period but still remained higher than the required levels despite the increased pressure and stress of past due, bad loans (see table 9). The lower incomes from remittances were not favorable for countries like Kosovo or Bosnia and Herzegovina. The deterioration of macroeconomic indicators, the contraction of Balkan economies in general and the increase in unemployment suppressed the demand for loans, although the interest rates declined continuously. The financial sector weaknesses were reflected mainly in the banking sector since all countries of Western Balkans have structured bank centered financial systems.

Considering the above mentioned, the paper is focused on evaluating relative efficiency using Data Envelopment Analysis as methodology. The paper is organized as below: the second section refers to literature review, the third to the methodologies used for evaluating efficiency focused in DEA. In the fourth section there are presented data and variables 
used for evaluating technical efficiency. In the fifth section there are summarized the results. Conclusions are presented in the last section.

\section{Literature Review}

There are no previous studies on evaluating Western Balkan countries banking sector efficiency from Albanian scholars whereas from other researchers. Based on evidences, Data Envelopment Analysis, as methodology, is widely used throughout the world by different scholars, researchers and academics for evaluating the efficiency and productivity of different organizations operating in sectors like: schools, hospitals, air-ports, banking sector etc, in US, England, Germany, China, Japan, Sweden, Malaysia, Australia, Greece, Italy, Turkey, Romania, Islamic countries etc.

Maredza, A., (2013), evaluated the changes in the efficiency and productivity during 2000-2010 using the twostage DEA methodology and concluded that the total factor of productivity was almost at $17 \%$ lower during crisis compared with the pre crisis period.

Alzubaidi, H., \& Bougheas, S., (WP 12/05) comparing 255 European Union Banks during 2005-2010 concluded that bank of Sweden and Denmark were the most efficient while banks of Belgium, Denmark, Ireland and Greece resulted the most affected by crisis. Both authors concluded that the commercial banks were more affected than other types of banks.

Popovici., M., MC., \& Cuza., I., A.., (2014) using the non-parametric approach examined the banks of Romania during 2003 - 2008 and 2009- 2013 which resulted in decreased efficiency during crisis period although banks reduced personnel costs during this period.

Wolters, M., E., Barbosa E., \& Felicio, J.A., (2014), analyzing the efficiency of banking sector, operating in a market oriented financial system, as that of Brazil, during the crisis of the year 2000, concluded that there is a negative impact of economic shock on the banking efficiency despite the size or type of ownership. The banks of small size were more affected than the larger ones. Banks which were under the control of the government were more efficient than the rest. During crisis the effectiveness of foreign-owned banks decreased more than that of national ones.

Avkiran, N.,K., \& Thoraneenitiyan., N., (2008), studied the relationship between the restructured banks after crisis (1997-2001), the particular conditions of a country and banks' efficiency. According to their evidences: a) the banking system proved not to be more efficient after restructuring, b) the efficiency was mainly affected by the economic conditions of a country, its economic development, increased interest rates, the concentration of the markets etc.

Yilmaz, A.A., (2013) analyzed thirty banks operating in Turkey during the period 2007-2010 and concluded that there was a declined trend of efficiency. According to the conclusions presented, the financial crisis was the reason for this decrease.

Khan, S.M.J., \& Wahab, N.,(2013), analyzed the banking system of Asia in post crisis period and concluded in positive trends of the banking sector efficiency due to the positive transformations of the banking sector, its consolidation and improvement of regulations.

Zeitun, R., \& Benjollun, H., (2012), analyzing the relative efficiency of twelve Jordanian banks during 2005-2010, concluded that the efficiency of banking sector was highly affected by crisis and suggested to managers and regulators take measures and further more investigate the reasons.

Dang -Thanh, Ngo.,(2013) investigated the trend of banking sector in Vietnam for the period 1990-2010 using macro indicators as the banking specific data were not available. They showed that there was deteriorated performance of the banking sector and that it was operating at one - fourth of its capacity. According to the author, the decreased efficiency was due to the openness and the liberalization of their economy.

The banking sector of Western Balkan countries is small according to its size but opened to the foreign capital inflows. During transition the foreign bank ownership "helped harden budget constraints and attain macroeconomic stability" Mitra, P., Selowsky, M., and Zalduendo, J., (2010, pg.10) while in crisis period "foreign banks exposed countries to considerable risk as did other foreign lenders" referring to Mitra, P., Selowsky, M., and Zalduendo, J., (2010, pg.9). The authors explain that main reason is the encouraged request for lending in Euro or Dollar currency because of higher domestic loan interest rates than the international market. According to the above mentioned authors"...the foreign ownership of the banking sector assets ... has a more dominant role...in Western Balkans" Mitra, P., Selowsky, M., and Zalduendo, J., (2010, pg.11). The potential presence of foreign capital especially in the banking sector of Western Balkans increased the involvement of these economies in the international market and banking sector. To avoid contagion phenomena, the countries under study have improved the banking regulations in accordance with the international standardized regulatory framework starting with the introduction of Basel II since 2011. The attentive and 
continuous monitoring of the sector is significantly important for the stability of financial system of these countries as a whole.

\section{Methods used for evaluating efficiency}

\subsection{Methods used for evaluating efficiency}

Efficiency monitoring and its evaluation, as two related but not same principles, are part of strategies and planning made by any organization because through them is provided the needed information to the management for reviewing the progress of the existing activity, for identifying and allocating properly inefficiencies and improving processes for better achievements.

Efficiency monitoring is considered as inestimable tool for managing properly and essential for its evaluation. "Efficiency monitoring is alike the 'check up' while its assessment with an 'autopsy' [Monitoring and Evaluating, 2014] according to their effects.

There are two approaches for evaluating efficiency: the accounting and the econometric one. The first, considered as traditional approach, refers to the evaluation of profitability indicators through financial ratio analysis. It is often used due to the ease of calculating and the few data required are taken from the financial statements of the activity. The financial ratios are mainly used in performance comparative studies. The above mentioned are the pros of using the financial ratio analysis but there are some drawbacks of using this method. The ratio indicators cannot present a complete overview of the financial performance of the activity as the data are obtained from the financial statements which are a snapshot of the activity at a given point in time. The few numbers/indicators used in ratio calculations limits the possibility of assessing the overall activity efficiency. The performance history analysis is not always a basis for predicting the activity progress and its future results.

The econometric approach consists in using two techniques for measuring efficiency: the parametric and nonparametric methods. Evaluating properly means modeling properly and prior to this the assessor must be focused on the inputs and outputs of the activity.

The parametric methods are used for measuring economic efficiency and are included the below:

- Stochastic Frontier Analysis (SFA)

- Distribution Free Approach (DFA)

- Thick Frontier Approach (TFA)

The non-parametric methods are used for technical efficiency assessment and are included the following:

- Data Envelopment Analysis (DEA)

- Free Disposable Hull Analysis (FDHA)

"The technical efficiency is the ability of a firm to obtain maximal output from a given set of inputs while the allocative efficiency is the ability to use the inputs in optimal proportions, given their respective prices. Their combination provides a measure of economic efficiency" Coelli, T.J., (CEPA WP 96/08, p.4). The best use of natural resources, reduced over time, and their proper allocation in a competitive environment with main tendency the increase of society welfare [Business Dictionary, 2014], refers to the economic efficiency [Tutor $2 u, 2014$ ]. In few words it is equivalent to product of more value than the used one, more production with less cost.

\subsection{Data Envelopment Analysis (DEA)}

According to Emrouznejad A., Parker, B., and Tavers, G., (2008) DEA is the mostly non-parametric method used in the banks' performance evaluation. Farrell, M.J., (1957), considering that efficiency originates from the production as economic phenomena, based on previous work of Debreu, G., (1951) who was the first to suggest how to measure the productive efficiency and that of Koopmans, T., (1951) who defined the technical efficiency, developed the modern concept of efficiency measurement using multiple inputs and outputs.

The model was designed, developed and presented by Charnes, Cooper and Rhodes (1978). According to Coelli, T., (CEPA WP 96/08, p.4)"the model is non-parametric as no prior function is required". The efficiency and the productivity of homogenous units, firms, processes regarded as Decision Making Units (DMUs) can be measured applying this model. Referring to Moffat, B., \& Valadkhani, A., (2008, p.3) "...each of mathematical programming DEA models used seeks to establish how the DMUs determine the envelopment surface, the best practice efficiency frontier". DEA estimates the efficiency relative to the frontier and surface defined as efficient and is used to analyze the existing 
relationship between the size of assets and return to scale.

According to Drake, L., (2001, p.557-571) the advantage is that "...DEA model works well with small sample size". The model become known and was extensively used to distinguish the changes in efficiencies among individual banks after being used from the author considering a sample of only nine of United State banks. According to Golany, B., \& Roll, Y., (1989, p. 237-250) DEA can provide accurate information for the ranking of units evaluated based on the efficiency results, can identify inefficiencies and help the management to improve processes. Referring to Berger, A.N., \& Mester, L.J., (1997, p.895-947), DEA, as a non-parametric model generally "do not allow for random error in the data and do not consider measurement error and luck of factors effecting efficiency estimates. Any deviation from the frontier reflects inefficiency. If there were any measurement errors they would be reflected in a change of measured efficiency". Berger, A.N., \& Humphrey, D.B, (1997, p.175-212) noted that "any of errors in one of the banks in the efficient frontier it may change the measured efficiency of all banks". One DMU is called efficient in case that DEA score is 1 and all slacks are 0 as per Cooper, W., Seiford, M.L., \& Tone, K., (2006, p.1270-1288). "The slack issue in DEA models disappear as the number of DMUs increases" Ji, Young-bae., \& Lee, Ch., (2010, p.270).

\section{Data and Methodology}

\subsection{Research Topics}

The intended objective of this paper is to assess the efficiency of Western Balkan countries' banking sector during the period $2007-2012$ by answering the following questions:

1. How is in terms of efficiency, the banking sector of Western Balkan countries presented during 2007-2012?

2. Has the 2008 crisis influenced the banking sector of Western Balkan countries?

\subsection{Data}

The sample used in the study includes data from the banking sector of six of seven Western Balkan countries: Albania, Bosnia \& Herzegovina, Kosovo, Macedonia FYR, Montenegro and Serbia all intending to become members of EU, excluding Croatia which is already part of it. We study this period because the crisis occurred during 2008-2012 and considering that these countries are recovering slowly since 2013 and ongoing. The vulnerabilities of the financial sector were reflected in the banking industry as key pillar of their financial structure. Considering the global diameters of the above mentioned crisis, the banking sector of these countries being foreign owned, was a threat to the stability of the financial system and their economic development. Additional reason is the availability of the data.A presence of varying efficiencies of each country since 2007 until 2012 is prepared. Data used are taken from secondary resources as published by Financial Sector Benchmarking Studies Database, 2013 (FSBSD, 2013) in the Regional Report of each country since the year 2007 up to 2012. For better examining the studied topic and more reliable results, must be used a sufficient number of units, DMUs. Each DMU in the study represents the banking sector of an individual country from the sample. According to Vassiloglu, M., \& Giokas, D., (1990, p.7) "the DMUs used in the sample must be three times the sum of inputs plus outputs". In this study is used DEAP 2.1 computing model and there is not any limitation on the number of DMUs used. There are presented different criteria from different scholars.

According to Ji, Young-bae., \& Lee., Ch., (2010, p.272), DEA "...has the ability to accommodate an unlimited number of inputs and outputs with an unlimited number of DMUs. The only limitation is the memory of PC".

For evaluating efficiency, the selection of variables (inputs \& outputs) is done according to the banks activity as specified in the literature as: a) the production approach that refers to banks as institutions which produce services and loans by managing deposits using labor and capital b) the primary, intermediary role of banks to accumulate capital from the savers and to allocate it in efficient investments (for example loans) for higher returns (as interests, fees, commissions etc) was the basis for the intermediation approach and the third one is assets approach. Other approaches consist in: user-cost, value added, profitability, equity, the modern approach related to information and risks management. All the presented are used from a number of researchers. The best used, as presented by Sealy, C.W., \& Lindley, J.T., (1977), is the intermediary and production approach.

In this paper the efficiency will be evaluated using the intermediation approach as presented by Avkiran, N.K., (2006) using the CRS assumption developed by Charner, Cooper and Rhodes (1978) and VRS developed by Banker, Charner and Cooper (1984), both models of DEA.

The CRS model consists in evaluating efficiency based on Constant Return to Scale, assumptions presenting the 
same change of outputs in case of a proportional change of inputs and the Variable Return to Scale refers to each DMU increasing or decreasing return to scale. The increasing return to scale is the situation where the input increases at a certain portion and the outputs increase more than that of inputs and the opposite refers to the decreased scale of return.

Table 1: CRS and VRS models of DEA, Coelli, T.J., $(1996$, pp.10, 18)

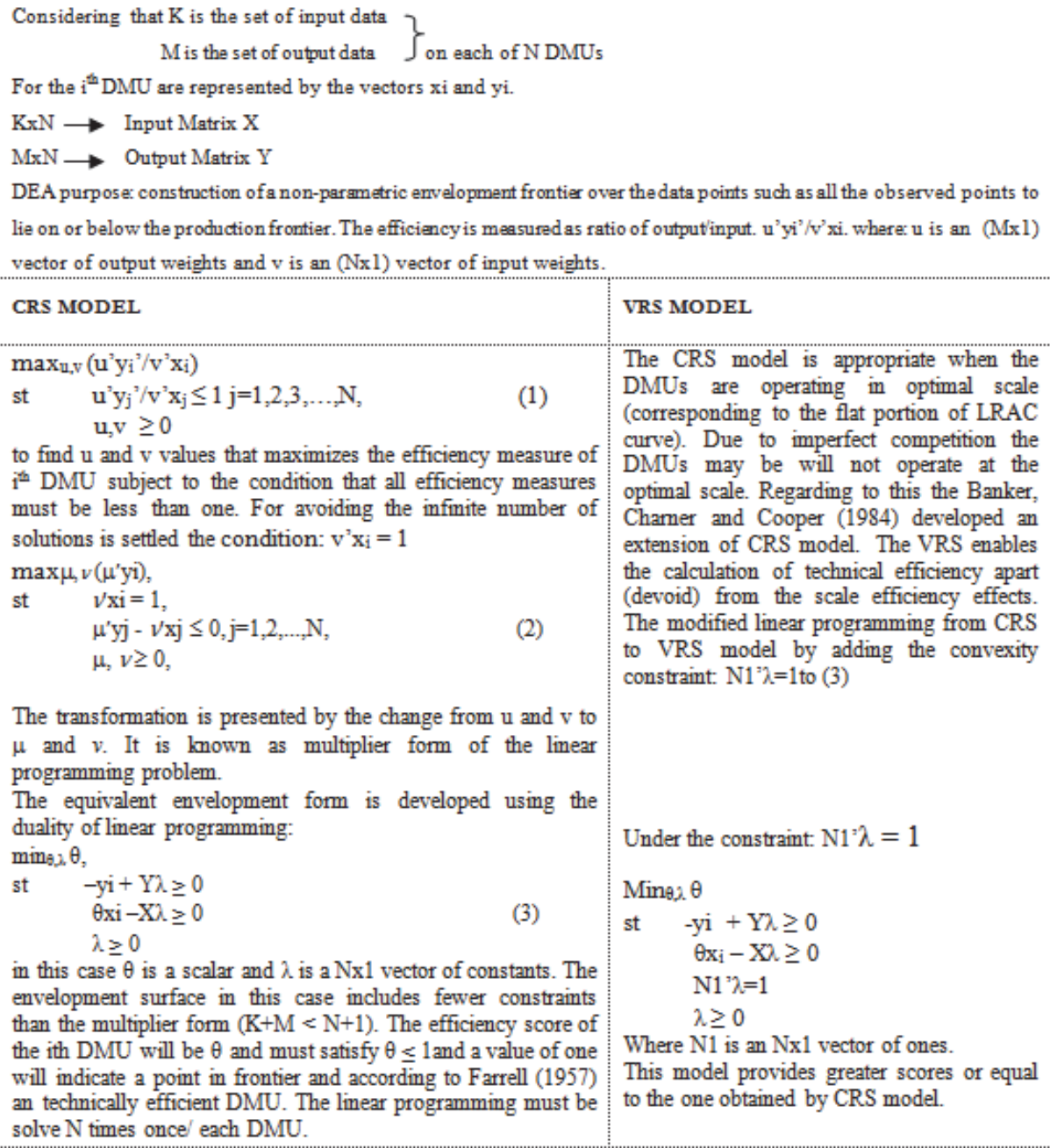

The transformation is presented by the change from $\mathrm{u}$ and $\mathrm{v}$ to $\mu$ and $v$. It is known as multiplier form of the linear programming problem.

The equivalent envelopment form is developed using the duality of linear programming:

in this case $\theta$ is a scalar and $\lambda$ is a Nx1 vector of constants. The envelopment surface in this case includes fewer constraints than the multiplier form $(\mathrm{K}+\mathrm{M}<\mathrm{N}+1)$. The efficiency score of the ith DMU will be $\theta$ and must satisfy $\theta \leq 1$ and a value of one will indicate a point in frontier and according to Farrell (1957) an technically efficient $\mathrm{DMU}$. The linear programming must be solve $\mathrm{N}$ times once/ each DMU.

\section{VRS MODEL \\ The CRS model is appropriate when the DMUs are operating in optimal scale (corresponding to the flat portion of LRAC curve). Due to imperfect competition the DMUs may be will not operate at the optimal scale. Regarding to this the Banker, Chamer and Cooper (1984) developed an extension of CRS model. The VRS enables the calculation of technical efficiency apart (devoid) from the scale efficiency effects. The modified linear programming from CRS to VRS model by adding the convexity} constraint: $\mathrm{N} 1^{3} \lambda=1$ to (3)

Under the constraint: $\mathrm{N}^{2} \lambda=1$

$\operatorname{Min} \vartheta, \lambda$

st $\quad-\mathrm{yi}+\mathrm{Y} \lambda \geq 0$

$\theta \mathrm{x}_{\mathrm{i}}-\mathrm{X} \lambda \geq 0$

$\mathrm{N} 1{ }^{\prime} \lambda=1$

$\lambda \geq 0$

Where N1 is an Nx1 vector of ones.

This model provides greater scores or equal to the one obtained by CRS model.

The variables employed in this paper are: $I_{1}$ - number of branches and $I_{2}$ - total assets while as output is used $\mathrm{O}_{1}$ - Total Loans

Table 2: Inputs and outputs used in CRS and VRS models of DEA, Intermediation Approach

\begin{tabular}{l|c|c|}
\hline $\mathrm{Nr}$ & Key Inputs & Key outputs \\
\hline $1^{*}$ & Subsidiaries/branches/offices \\
\hline $2^{* *}$ & Deposits \\
* The number of branches is calculates per 1,000 km² \\
** Total assets and loans are presented as \% of GDP (weighted indicators)
\end{tabular}

Considering that DEA does not require any specification of the function of performance frontier possibilities it can be "... an alternative method of analyzing financial ratios which do not depend on unsustainable assumptions.DEA is a freedistribution method and does not assign pre-specified weights. It can provide aggregate measures of efficiency using multiple outputs and inputs as indicators of performance" Emrouznejad A., Parker, B., and Tavers, G., (2008, p.151-157). 


\subsection{Empirical Results}

After examining the efficiency change of WB countries banking sector during the period 2007-2012 using both CRS \&VRS DEA models and the intermediation approach, the results are as presented in Tables 3, 4 and 5 . Means of technical, constant, variable and scale efficiency of countries 'sample' are presented in the Tables 10 and 11.The tests are made for each country at each year of the studied period. Referring to the efficiency scores results that the banking sector of the examined countries has operated under their full capacity as the average technical efficiency for the period 2007-2012 is at 0.686 or at $68.6 \%$. The average TE for all WB countries in the year 2007 was 0.666 or at $66.6 \%$, decreased during the years 2008 and 2009 at $0.601(60.1 \%)$ and $0.639(63.9 \%)$ respectively.

The banking sector has been affected by crisis and economic shocks of the period. It is reflected in the decreased performance indicators ROE and ROA (table 7 and 8), increased non-performing loans (table 8) etc. There is a slight improvement in the year 2010 (as the TE is at 0.673 or $67.3 \%$ ) and an increased trend in the year 2011 and 2012.Albania results with the lowest average efficiency score during the period 2007-2012. The average efficiency score of Albanian banking sector for the whole period under study is at 0.433 (or at $43,3 \%$ of the total capacity), an average constant return to scale at $0.421(42.1 \%)$, variable return to scale averagely at $0.783(78.3 \%)$ and scale efficiency at $0.544(54.4 \%)$.

The potential presence of foreign capital and ownership in the Albanian banking industry, typical of the entire banking sector of Western Balkans, influenced the sector developments especially during the years $2008-2009$. Considering the Albanian experience, the branches of Greek and Italian banks operating in the countries of Western Balkans were obliged to change their strategies to respond to the clients' panic caused by the financial and economic situation of parent countries. These banks offered higher deposit interest rates than other banks operating in the country owned by Austrian, Turkish or French capital/owners to keep the clients who were massively withdrawing their money. These banks burst with new products especially retail and consumer loans offered at preferential interest rates. The impact was the decreased performance indicators (explained in the table 7 and 8). The banking sector improved in the late 2011 and the year 2012 as result of regulatory changes and increased supervision, improvements in capitalization and the management of increased past due and non performing loans. Considering the central banks' financial reports of countries under study all have been able to manage crisis. Albania firstly introduced the banking regulatory changes in the year 2011 helping so to manage the contagion effects related to Greece and Italia, increased the banks' capitalization at the required levels, their liquidity and reviewed the managing of non-performing loans policies. Montenegro and Bosnia \& Herzegovina result to have been more efficient during the years 2011 and 2012 as the situation in the banking sector during the year 2011 was considerably improved. To the foreign owners was required to recapitalize their branches and to provide sufficient liquidity in the operating system. Banks sold out their non-performing and write off loans to factoring or executor companies, or parent banks. The banking sector efficiency of Kosovo needs improvements as its average technical efficiency for the whole period under study results to be at 0.481 or at $48.1 \%$. Average technical efficiency indicator for Macedonia FYR for the period 2007-2012 is at 0.616 or at $61.6 \%$ while for Serbia results to be at 0.657 or at $65.7 \%$. Constant return to scale results same as TE. The average variable return to scale for the banking sector of all countries under study, is higher than the constant return to scale but results to be at a decreased trend from 2007 at 0.964 (or $96.4 \%$ ) to 0.908 (or at $90.8 \%$ ) in the year 2012. The trend of average scale efficiency is the same with the trend of TE, decreased in the year 2008 and 2009 compared with 2007 but increased during 2011 and 2012.

Table 3: Efficiency Scores of WB countries in 2007 to 2012

\begin{tabular}{|c|c|c|c|c|c|c|c|c|}
\hline Albania & 2007 & 2008 & 2009 & 2010 & 2011 & 2012 & Mean \\
\hline TE & 0.321 & 0.324 & 0.463 & 0.419 & 0.526 & 0.546 & 0.433 \\
\hline Crste & 0.321 & 0.324 & 0.392 & 0.419 & 0.526 & 0.546 & 0.421 \\
\hline Vrste & 0.840 & 0.800 & 0.818 & 0.744 & 0.748 & 0.750 & 0.783 \\
\hline Scale & 0.382 & 0.405 & 0.479 & 0.564 & 0.703 & 0.728 & 0.544 \\
\hline B \&H & 2007 & 2008 & 2009 & 2010 & 2011 & 2012 & Mean \\
\hline TE & 1.000 & 0.830 & 0.904 & 0.899 & 1.000 & 1.000 & 0.939 \\
\hline Crste & 1.000 & 0.830 & 0.904 & 0.899 & 1.000 & 1.000 & 0.939 \\
\hline Vrste & 1.000 & 1.000 & 1.000 & 0.951 & 1.000 & 1.000 & 0.992 \\
\hline Scale & 1.000 & 0.830 & 0.904 & 0.946 & 1.000 & 1.000 & 0.947 \\
\hline
\end{tabular}




\begin{tabular}{|c|c|c|c|c|c|c|c|}
\hline Kosovo & 2007 & 2008 & 2009 & 2010 & 2011 & 2012 & Mean \\
\hline TE & 0.524 & 0.423 & 0.417 & 0.461 & 0.527 & 0.531 & 0.481 \\
\hline Crste & 0.524 & 0.423 & 0.417 & 0.461 & 0.527 & 0.531 & 0.481 \\
\hline Vrste & 1.000 & 0.926 & 0.854 & 0.834 & 0.870 & 0.899 & 0.897 \\
\hline Scale & 0.524 & 0.457 & 0.489 & 0.553 & 0.606 & 0.590 & 0.537 \\
\hline
\end{tabular}

\begin{tabular}{|c|c|c|c|c|c|c|c|}
\hline Macedonia FYR & 2007 & 2008 & 2009 & 2010 & 2011 & 2012 & Mean \\
\hline TE & 0.556 & 0.463 & 0.545 & 0.570 & 0.744 & 0.816 & 0.616 \\
\hline Crste & 0.556 & 0.463 & 0.545 & 0.570 & 0.744 & 0.816 & 0.616 \\
\hline Vrste & 1.000 & 0.949 & 0.951 & 0.856 & 0.917 & 0.905 & 0.930 \\
\hline Scale & 0.556 & 0.487 & 0.573 & 0.666 & 0.811 & 0.902 & 0.666 \\
\hline
\end{tabular}

\begin{tabular}{|c|c|c|c|c|c|c|c|}
\hline Serbia & 2007 & 2008 & 2009 & 2010 & 2011 & 2012 & Mean \\
\hline TE & 0.595 & 0.569 & 0.576 & 0.688 & 0.753 & 0.763 & 0.657 \\
\hline Crste & 0.595 & 0.569 & 0.576 & 0.688 & 0.753 & 0.763 & 0.657 \\
\hline Vrste & 0.942 & 1.000 & 0.934 & 0.865 & 0.900 & 0.896 & 0.923 \\
\hline Scale & 0.632 & 0.569 & 0.617 & 0.795 & 0.836 & 0.851 & 0.717 \\
\hline
\end{tabular}

*All the efficiency scores of Montenegro results to be 1 (efficient).

\section{Conclusions}

In the presented paper is evaluated the efficiency of the banking sector of Western Balkan countries. The number of countries/units in the sample is six and the banking efficiency is investigated for the period between 2007 and 2012. According to the results, the banking sector of Western Balkan countries has an average technical score for the whole studied period at 0.686 or $68.6 \%$ same as technical efficiency from CRS DEA (crste), technical efficiency from VRS DEA (vrste) at $0.921(92.1 \%)$ and scale (crste/vrste) at 0.735(73.5\%) (table 9). The minimum average technical efficiency

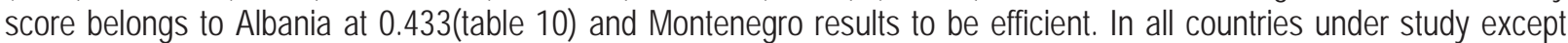
Albania there is a decrease in the average technical efficiency scores during crisis (2008 \&2009), improved in the recovery period. This score is slightly increased during 2010 and after. In the VRS/intermediation model the banking sector has experienced increasing return to scale. This study can be represented by analyzing the banking sector efficiency using different variables. There must be applied regression analysis to identify the variables influencing more the performance indicators as the decrease in ROA for Montenegro is contrary to efficiency score.

Table 4: Western Balkans' banking sector Technical Efficiency Scores (CRS model)

\begin{tabular}{|c|c|}
\hline SCALE ASSUMPTION CRS/ SCLACKS MULTI-STAGE METHOD \\
\hline 2007 & TE \\
\hline Albania & 0.321 \\
\hline Bosnia \& Herzegovina & 1.000 \\
\hline Kosovo & 0.524 \\
\hline Macedonia FYR & 0.556 \\
\hline Montenegro & 1.000 \\
\hline Serbia & 0.595 \\
\hline Mean & 0.666 \\
\hline 2008 & 0.324 \\
\hline Albania & 0.830 \\
\hline Bosnia \& Herzegovina & 0.423 \\
\hline Kosovo & 0.463 \\
\hline Macedonia FYR & 1.000 \\
\hline Montenegro & 0.569 \\
\hline Serbia & 0.601 \\
\hline Mean & 0.463 \\
\hline 2009 & 0.904 \\
\hline Albania & 0.417 \\
\hline Bosnia \& Herzegovina & \\
\hline Kosovo & \\
\hline & \\
\hline
\end{tabular}




\begin{tabular}{|c|c|}
\hline Macedonia FYR & 0.545 \\
\hline Montenegro & 1.000 \\
\hline Serbia & 0.576 \\
\hline Mean & 0.639 \\
\hline \multicolumn{2}{|l|}{2010} \\
\hline Albania & 0.419 \\
\hline Bosnia \& Herzegovina & 0.899 \\
\hline Kosovo & 0.461 \\
\hline Macedonia FYR & 0.570 \\
\hline Montenegro & 1.000 \\
\hline Serbia & 0.688 \\
\hline Mean & 0.673 \\
\hline \multicolumn{2}{|l|}{2011} \\
\hline Albania & 0.526 \\
\hline Bosnia \& Herzegovina & 1.000 \\
\hline Kosovo & 0.527 \\
\hline Macedonia FYR & 0.744 \\
\hline Montenegro & 1.000 \\
\hline Serbia & 0.753 \\
\hline Mean & 0.758 \\
\hline \multicolumn{2}{|l|}{2012} \\
\hline Albania & 0.546 \\
\hline Bosnia \& Herzegovina & 1.000 \\
\hline Kosovo & 0.531 \\
\hline Macedonia FYR & 0.816 \\
\hline Montenegro & 1.000 \\
\hline Serbia & 0.763 \\
\hline Mean & 0.776 \\
\hline
\end{tabular}

Table 5: Western Balkans' Banking sector Efficiency Scores (VRS DEA)

\begin{tabular}{|c|c|c|c|c|}
\hline \multicolumn{5}{|c|}{ INPUT ORIENTED DEA/ SCALE ASSUMPTION VRSI SCLACKS MULTI-STAGE METHOD } \\
\hline 2007 & crste & vrste & scale & IRS/DRS \\
\hline Albania & 0.321 & 0.840 & 0.382 & Irs \\
\hline Bosnia \& Herzegovina & 1.000 & 1.000 & 1.000 & - \\
\hline Kosovo & 0.524 & 1.000 & 0.524 & Irs \\
\hline Macedonia FYR & 0.556 & 1.000 & 0.556 & IrS \\
\hline Montenegro & 1.000 & 1.000 & 1.000 & - \\
\hline Serbia & 0.595 & 0.942 & 0.632 & IrS \\
\hline Mean & 0.666 & 0.964 & 0.682 & \\
\hline \multicolumn{5}{|l|}{2008} \\
\hline Albania & 0.324 & 0.800 & 0.405 & IrS \\
\hline Bosnia \& Herzegovina & 0.830 & 1.000 & 0.830 & IrS \\
\hline Kosovo & 0.423 & 0.926 & 0.457 & IrS \\
\hline Macedonia FYR & 0.463 & 0.949 & 0.487 & IrS \\
\hline Montenegro & 1.000 & 1.000 & 1.000 & - \\
\hline Serbia & 0.569 & 1.000 & 0.569 & IrS \\
\hline Mean & 0.601 & 0.946 & 0.625 & \\
\hline \multicolumn{5}{|l|}{2009} \\
\hline Albania & 0.392 & 0.818 & 0.479 & Irs \\
\hline Bosnia \& Herzegovina & 0.904 & 1.000 & 0.904 & IrS \\
\hline Kosovo & 0.417 & 0.854 & 0.489 & Irs \\
\hline Macedonia FYR & 0.545 & 0.951 & 0.573 & Irs \\
\hline Montenegro & 1.000 & 1.000 & 1.000 & - \\
\hline Serbia & 0.576 & 0.934 & 0.617 & IrS \\
\hline Mean & 0.639 & 0.926 & 0.677 & \\
\hline 2010 & & & & \\
\hline
\end{tabular}




\begin{tabular}{|c|c|c|c|c|}
\hline Albania & 0.419 & 0.744 & 0.564 & Irs \\
\hline Bosnia \& Herzegovina & 0.899 & 0.951 & 0.946 & Irs \\
\hline Kosovo & 0.461 & 0.834 & 0.553 & Irs \\
\hline Macedonia FYR & 0.570 & 0.856 & 0.666 & Irs \\
\hline Montenegro & 1.000 & 1.000 & 1.000 & - \\
\hline Serbia & 0.688 & 0.865 & 0.795 & Irs \\
\hline Mean & 0.673 & 0.875 & 0.754 & \\
\hline \multicolumn{5}{|l|}{2011} \\
\hline Albania & 0.526 & 0.748 & 0.703 & Irs \\
\hline Bosnia \& Herzegovina & 1.000 & 1.000 & 1.000 & - \\
\hline Kosovo & 0.527 & 0.870 & 0.606 & Irs \\
\hline Macedonia FYR & 0.744 & 0.917 & 0.811 & Irs \\
\hline Montenegro & 1.000 & 1.000 & 1.000 & - \\
\hline Serbia & 0.753 & 0.900 & 0.836 & Irs \\
\hline Mean & 0.758 & 0.906 & 0.826 & \\
\hline \multicolumn{5}{|l|}{2012} \\
\hline Albania & 0.546 & 0.750 & 0.728 & Irs \\
\hline Bosnia \& Herzegovina & 1.000 & 1.000 & 1.000 & - \\
\hline Kosovo & 0.531 & 0.899 & 0.590 & Irs \\
\hline Macedonia FYR & 0.816 & 0.905 & 0.902 & Irs \\
\hline Montenegro & 1.000 & 1.000 & 1.000 & - \\
\hline Serbia & 0.763 & 0.896 & 0.851 & Irs \\
\hline Mean & 0.776 & 0.908 & 0.845 & \\
\hline
\end{tabular}

Table 6: Banking sector Efficiency Score (VRS DEA) by country

\begin{tabular}{|c|c|c|c|}
\hline \multicolumn{4}{|c|}{ INPUT ORIENTED DEA/ SCALE ASSUMPTION VRS/ SCLACKS MULTI-STAGE METHOD } \\
\hline Albania & crste & vrste & Scale \\
\hline 2007 & 0.321 & 0.840 & 0.382 \\
\hline 2008 & 0.324 & 0.800 & 0.405 \\
\hline 2009 & 0.392 & 0.818 & 0.479 \\
\hline 2010 & 0.419 & 0.744 & 0.564 \\
\hline 2011 & 0.526 & 0.748 & 0.703 \\
\hline 2012 & 0.546 & 0.750 & 0.728 \\
\hline Mean & 0.421 & 0.783 & 0.544 \\
\hline \multicolumn{4}{|c|}{ Bosnia \& Herzegovina } \\
\hline 2007 & 1.000 & 1.000 & 1.000 \\
\hline 2008 & 0.830 & 1.000 & 0.830 \\
\hline 2009 & 0.904 & 1.000 & 0.904 \\
\hline 2010 & 0.899 & 0.951 & 0.946 \\
\hline 2011 & 1.000 & 1.000 & 1.000 \\
\hline 2012 & 1.000 & 1.000 & 1.000 \\
\hline Mean & 0.939 & 0.992 & 0.947 \\
\hline \multicolumn{4}{|l|}{ Kosovo } \\
\hline 2007 & 0.524 & 1.000 & 0.524 \\
\hline 2008 & 0.423 & 0.926 & 0.457 \\
\hline 2009 & 0.417 & 0.854 & 0.489 \\
\hline 2010 & 0.461 & 0.834 & 0.553 \\
\hline 2011 & 0.527 & 0.870 & 0.606 \\
\hline 2012 & 0.531 & 0.899 & 0.590 \\
\hline Mean & 0.481 & 0.897 & 0.537 \\
\hline \multicolumn{4}{|c|}{ Macedonia FYR } \\
\hline 2007 & 0.556 & 1.000 & 0.556 \\
\hline 2008 & 0.463 & 0.949 & 0.487 \\
\hline 2009 & 0.545 & 0.951 & 0.573 \\
\hline 2010 & 0.570 & 0.856 & 0.666 \\
\hline 2011 & 0.744 & 0.917 & 0.811 \\
\hline
\end{tabular}




\begin{tabular}{|c|c|c|c|}
\hline 2012 & 0.816 & 0.905 & 0.902 \\
\hline Mean & 0.616 & 0.930 & 0.666 \\
\hline Serbia & & & \\
\hline 2007 & 0.595 & 0.942 & 0.632 \\
\hline 2008 & 0.569 & 1.000 & 0.569 \\
\hline 2009 & 0.576 & 0.934 & 0.617 \\
\hline 2010 & 0.688 & 0.865 & 0.795 \\
\hline 2011 & 0.753 & 0.900 & 0.836 \\
\hline Mean & 0.763 & 0.896 & 0.851 \\
\hline
\end{tabular}

Note: The technical efficiency, technical efficiency CRS DEA, technical efficiency VRS DEA and scale efficiency of Montenegro have scored 1 (see tables $4 \& 5$ ).

Table 7: Return on Assets, in \% (ROA)

\begin{tabular}{|c|c|c|}
\hline Geo/Time & Pre Crisis (Average) & During Crisis (Average) \\
\hline Albania & $\mathbf{2 0 0 5 - 2 0 0 7}$ & $\mathbf{2 0 0 8 - 2 0 1 4}$ \\
\hline Bosnia and Herzegovina & 1.47 & 0.57 \\
\hline Croatia & 0.83 & 0.25 \\
\hline Kosovo & 1.57 & 0.76 \\
\hline Macedonia, FYR & n/a & 0.70 \\
\hline Montenegro & 1.60 & 0.50 \\
\hline Serbia & 0.87 & -1.02 \\
\hline
\end{tabular}

Source: Elaborated data extracted from Global Financial Stability Report (IMF) and Bank of Albania for Albania. Retrieved from: http://data.worldbank.org/indicator/FM.AST.CGOV.ZG.M3/countries; Accessed on November 15, 2014 (Varesi, L., 2014)

Table 8: Return on Equity, in \% (ROE)

\begin{tabular}{|c|c|c|}
\hline \multirow{2}{*}{ Geo/Time } & Pre Crisis (Average) & During Crisis (Average) \\
\cline { 2 - 3 } & $\mathbf{2 0 0 5 - 2 0 0 7}$ & $\mathbf{2 0 0 8 - 2 0 1 4}$ \\
\hline Albania & 20.97 & 5.76 \\
\hline Bosnia and Herzegovina & 7.87 & 2.23 \\
\hline Croatia & 12.90 & 5.11 \\
\hline Kosovo & n/a & 7.37 \\
\hline Macedonia, FYR & 11.60 & 4.49 \\
\hline Montenegro & 5.73 & -10.18 \\
\hline Serbia & 8.97 & 3.77 \\
\hline
\end{tabular}

Source: Elaborated data extracted from Global Financial Stability Report (IMF), October 2009, Bank of Albania for Albania. Retrieved from:http://data.worldbank.org/indicator/FM.AST.CGOV.ZG.M3/countries; Accessed on November 15, 2014 (Varesi, L.,2014)

Table 9: Non - performing loans to total loans (in \%) for WB countries during 2007-2012

\begin{tabular}{|c|c|c|c|c|c|c|}
\hline NPL/TL (in \%) & $\mathbf{2 0 0 7}$ & $\mathbf{2 0 0 8}$ & $\mathbf{2 0 0 9}$ & $\mathbf{2 0 1 0}$ & $\mathbf{2 0 1 1}$ & $\mathbf{2 0 1 2}$ \\
\hline Albania & 3.40 & 6.60 & 10.50 & 14.00 & 18.80 & 22.50 \\
\hline Bosnia \& Herzegovina & 3.00 & 3.00 & 5.90 & 11.40 & 11.90 & 12.60 \\
\hline Kosovo & 4.10 & 3.30 & 4.30 & 5.20 & 5.70 & 6.40 \\
\hline Macedonia FYR & 7.50 & 6.80 & 8.90 & 9.00 & 9.50 & 9.70 \\
\hline Montenegro & 3.20 & 7.20 & 13.50 & 21.00 & 15.50 & 17.60 \\
\hline Serbia & 8.40 & 11.30 & 15.50 & 16.90 & 19.03 & 18.63 \\
\hline
\end{tabular}

Source: http://www.pfsprogram.org/sites/default/files/Albania_FSBS_11-15-2013.pdf; Accessed on November 15, 2014 (Varesi L.,2014) 
Non-performing loans to total loans (in \%)

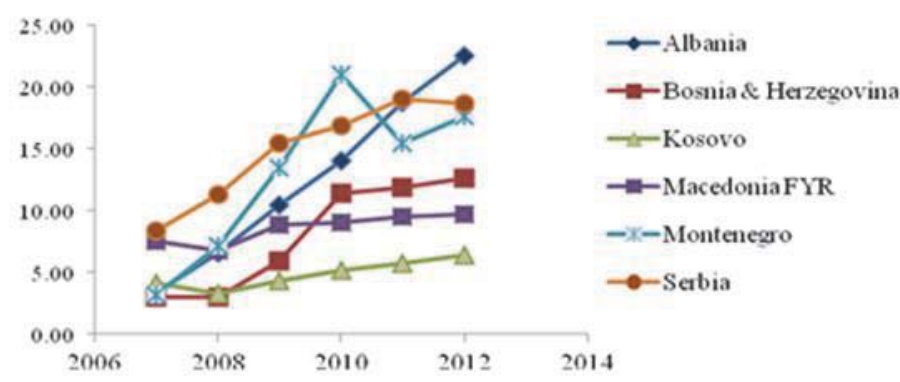

Table 10: Means of TE, crste, vrste, scale efficiency Scores for the period 2007-2012

\begin{tabular}{|c|c|c|c|c|}
\hline WB countries in total/'07-'12 & TE & crste & vrste & Scale \\
\hline 2007 & 0.666 & 0.666 & 0.964 & 0.682 \\
\hline 2008 & 0.601 & 0.601 & 0.946 & 0.625 \\
\hline 2009 & 0.639 & 0.639 & 0.926 & 0.677 \\
\hline 2010 & 0.673 & 0.673 & 0.875 & 0.754 \\
\hline 2011 & 0.758 & 0.758 & 0.906 & 0.826 \\
\hline 2012 & 0.776 & 0.776 & 0.908 & 0.845 \\
\hline Total & 0.686 & 0.686 & 0.921 & 0.735 \\
\hline
\end{tabular}

Table 11: Means of TE, crste, vrste, scale efficiency Scores for the period 2007-2012

\begin{tabular}{|c|c|c|c|c|}
\hline Mean per country/'07-'12 & TE & crste & vrste & Scale \\
\hline Albania & 0.433 & 0.421 & 0.783 & 0.544 \\
\hline Bosnia \& Herzegovina & 0.939 & 0.939 & 0.992 & 0.947 \\
\hline Kosovo & 0.481 & 0.481 & 0.897 & 0.537 \\
\hline Macedonia FYR & 0.616 & 0.616 & 0.930 & 0.666 \\
\hline Montenegro* & 1.000 & 1.000 & 1.000 & 1.000 \\
\hline Serbia & 0.617 & 0.614 & 0.901 & 0.673 \\
\hline
\end{tabular}

Mean of TE, crste, vrste, scale 2007-2012

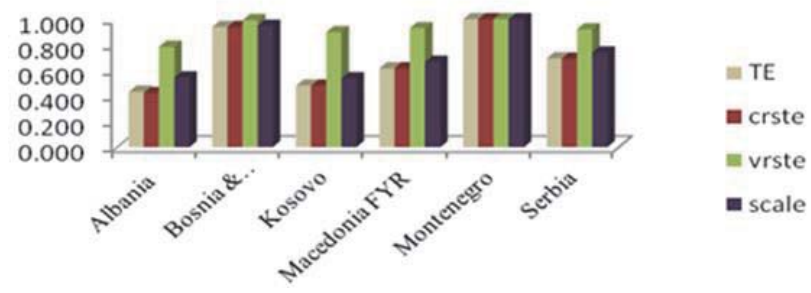

\section{References}

Alzubaidi, H., \& Bougheas, S., (WP 12/05), The Impact of the Global Financial Crisis on European Banking Efficiency, Working Paper 12/05 (CFCM), produced by: Center for Finance and Credit Markets, School of Economics, Sir Clive Granger Building, University Park, Nottingham NG7 2RD.Available on:http://www.nottingham.ac.uk; Accessed on December 27, 2014.Available on:http://www.une.edu.au/econometrics/cepa.htm;

Avkiran, N., K (2013), Bank Efficiency Measurement and Network DEA: A Discussion of Key Issues and Illustrations of Recent Developments in the Field, in Pasiouras, F., Efficiency and Productivity Growth: Modeling in the Financial Services Industry, Chapter 8, pg., 171-191.Published by: John Wiley \& Sons Ltd

Avkiran, N.,K., Thoraneenitiyan., N.,(2008), Measuring the impact of restructuring and country specific-factors on the efficiency of post crisis - East Asian banking systems: Integrating DEA with SFA, @ 2008 Published by: Elsevier Ltd. Retrieved from: http://www.sciencedirect.com, Accessed on: December 28, 2014. 
Avkiran, N.K.,(2006), "Developing foreign bank efficiency models for DEA grounded in finance theory”, pg.292. Published by: SocioEconomic Planning Sol.40, pg. 275-296

Avkiran, N.K.,(2006), "Developing foreign bank efficiency models for DEA grounded in finance theory”, pg.292. Published by: SocioEconomic Planning Sol.40, pg. 275-296

Banker, R.D., Charners, A.,\& Cooper W.W., (1984),"Some models for estimating technical and scale inefficiencies in data envelopment analysis". Management Science, Vol.30, Nr.9, Pg. 1078-1092.

Banker, R.D., Charners, A.,\& Cooper W.W., (1984),"Some models for estimating technical and scale inefficiencies in data envelopment analysis". Management Science, Vol.30, Nr.9, Pg. 1078-1092

Berger, A.N., \& Mester, L.J.,(1997), "Inside the Black Box: What explains differences in the efficiencies of financial institutions?'Published by: Journal of Banking and Finance,Vol.21, Pg.895-947.

Berger, A.N., \&Humphrey, D.B, (1997), "Efficiency of financial institutions: International Survey and directions of future research". Published by: European Journal of Operational Research Vol.98, Pg.175-212

Buss Dictionary, Economic Efficiency, Definition, Retracted by: http://www.businessdictionary.com/definition/economic-efficiency.html Accessed on January 6, 2015

Charner, A., Cooper, W.W., \& Rhodes, E., (1978), "Measuring the efficiency of decision making units". European Journal of Operational Research, Vol.2, Nr.6, Pg.429-444.

Coelli, T.J., (1996), "A guide to DEAP, Version 2.1: A Data Envelopment Analysis (Computer) Program", No.8/96, pg.4 CEPA Working Paper; Published by: The University of New England (UNE), Armidale, NSW 2351, Australia. Available on: http://www.une.edu. au/econometrics/cepawp.htm

Coelli, T.J.,(8/96), "A Guide to DEAP Version 2.1: A Data Envelopment Analysis (Computer) Program", pg.10 Working Paper published by: Centre for Efficiency and Productivity Analysis, Department of Econometrics, University of New England, Armidale, NSW, 2351, Australia; pg.4; authors' e-mail tcoelli@metz.une.edu.au;

Coelli, T.J.,(8/96,), "A Guide to DEAP Version 2.1: A Data Envelopment Analysis (Computer) Program”, pg.18 Working Paper published by: Centre for Efficiency and Productivity Analysis, Department of Econometrics, University of New England, Armidale, NSW, 2351, Australia; pg.4; authors' e-mail tcoelli@metz.une.edu.au;

Cooper, W., Seiford, M.L., \& Tone, K.,(2006), “Introduction to Data Envelopment Analysis and Its Uses”. Published: New York: Springer.

Dang -Thanh, Ngo.,(2013),Vitenam National University, The Performance of Vietnamese Banking System Under Financial Liberalization, Measurement using DEA (July 06, 2012). Available at SSRN: http://ssrn.com/abstract=2136150 or orhttp://dx.doi.org/10.2139/ssrn.2136150

Debreu, G., (1951), "The coefficient of resource allocation", Econometrica,Vol.19, Nr.3, Pg.273-292.

Drake, L.,(2001),"Efficiency and Productivity change in UK banking”, Published in: Applied Financial Economics, Vol.11, No.5, pg. 557571

Emrouznejad A.,Parker, B., and Tavers. G.,(2008), "A bibliography of data envelopment analysis", Socio-Economic Planning Science,Vol.42, No.3, pg. 151-157

Emrouznejad A.,Parker, B., and Tavers. G.,(2008), "A bibliography of data envelopment analysis", Socio-Economic Planning Science, Vol.42,Nr.3, pg. 151-157

Favero, C., \& Papi, L., (1995), "Technical Efficiency and Scale Efficiency in the Italian banking sector. A non parametric approach”, Applied Economics, Vol.27, pg.385-395.

Financial Sector Benchmarking System, 2013.Regional Benchmarking Report, November 2013, pg. 2, prepared by the Partners For Financial Stability Program, Deloitte Consulting, LLC for USAID, USAID from the American people. Retrieved from: http://www.pfsprogram.org/, Accessed on: December 27, 2014.

Financial Sector Benchmarking System, 2013.Regional Benchmarking Report, November 2013, pg. 3, prepared by the Partners For Financial Stability Program, Deloitte Consulting, LLC for USAID, USAID from the American people. Retrieved from: http://www.pfsprogram.org/, Accessed on: December 27, 2014.

Financial Stability Report, 2014 H1. International Developments, pg.21-22 Retrieved from: http://www.bankofalbania.org/, Accessed on: December 27, 2014.

FSBSD stands for Financial Sector Benchmarking Studies Database, 2013.

Golany, B., \& Roll, Y., (1989), "An application procedure for DEA", Published by: Omega, Vol.17, pg.237-250.

Ji, Young-bae., \& Lee., Ch.,(2010), Korea National Defense University, Seoul, Republic of Korea, "Data Envelopment Analysis", Vol.10, Nr. 2, pg.270.Published by: The Stata Journal (2010). Authors' e-mails: jyb@hanmail.net \& sarang96@kndu.ac.kr; accessed on: December 28, 2014.

Ji, Young-bae., \& Lee., Ch.,(2010), Korea National Defense University, Seoul, Republic of Korea, "Data Envelopment Analysis”, Vol.10, Nr.2, pg.272, Published by: The Stata Journal (2010). Authors' e-mails: jyb@hanmail.net \& sarang96@kndu.ac.kr; accessed on: December 28, 2014.

Khan, S.M.J., \& Wahab, N.,(2013), Post Asian Crisis Experience on Bank Efficiency and Competition, Published by: PAK Publishing Book, Growing Knowledge for Future, Proceeding Book of ICEFMO, 2013, Malaysia, handbook on the Economic, Finance and Management Outlooks, Retrieved from: http://www.pakinsight.com; Accessed on: December 28, 2014.

Koopmans, T.,(1951), "An analysis of production as an efficient combination of activities", in: Activity Analysis of Production and Allocation, Cowles Commission for Research in Economies, Monograph 13, New York.

Maredza, A., \& Ikhide, S., (2013), The Impact of Financial Crisis in Efficiency and Productivity of the Banking System in South Africa, 
paper published by: Economic Research Southern Africa ERSA January 2013.Available on: www.researchgate.net Accessed on December 27, 2014.

Moffat, B., \& Valadkhani, A., (2008), University of Wollongong, "Technical Efficiency in Botswana's financial institutions: a DEA Approach", pg.3, Faculty of Business - Economics Working Papers, Published by: University of Wollongong Research Online. Authors e-mail: abbas@uow.edu.au. Retrieved from: http://ro.uow.edu.au; Accessed on: December 28, 2014.

Monitoring and Evaluating, Available on: http://www.incitedirectives.com/_blog/News/post/efficiency-goals-part-of-strategic-planning/; Accessed on: November 23, 2014; 15:42

Popovici., M., MC., \& Cuza., I., A.., (2014), Doctoral School of Economics and Business Administration, lasi, Romania, Impact of financial crisis on banking efficiency: Evidence from Rumania, published by: SEA-Practical Application of Science, Volume II, Issue 1(3)/2014. Available on: http://sea.bxb.ro/Article/SEA_3_55.pdf; Accessed on December 27, 2014

Sealy, C.W., \& Lindley,J.T.,(1977), "Inputs, outputs and theory of production and costs at depository financial institution", Journal of Finance, 34, 1251-66.

Mitra, P., Selowsky, M., and Zalduendo, J., (2010), "TWENTY, Recession, Recovery and Reform in the Central and Eastern Europe and the Former Soviet Union”, pg.10, @2010, The International Bank for Reconstruction and Development/ The World Bank, 1818, Washington, DC 20433, www.worldbank.org. Available in: https://books.google.al, Accessed on January 06, 2015.

Seifeord, L., \& Zhu J., (1999), "The two approaches used for evaluating the banking performance" were presented by, "Profitability and marketability of the top 55 US commercial banks", Management Science, Vol.45. Nr.9, pg. 1270-1288.

Tutor 2u, Economic Efficiency, Retracted by: http://www.tutor2u.net/economics/content/topics/competition/efficiency.htm; Accessed on January 6,2015

Varesi, L., 2014 "The performance of Banking Sector in Terms of Macroeconomic and Bank Specific Determinants; Case of Western Balkan countries; Cross - country, comparative study" In publishing process from: http://journals.univ-danubius.ro/index. php/oeconomica/author

Vassiloglu, M. \& Giokas, D., (1990), "A study of the relative efficiency of bank branches: An application of data envelopment analysis", Journal of Operation Research Society Vol.41, Nr.7

Wolters, M., E., Barbosa E., \& Felicio, J.A., (2014), The effects of the global financial crisis on Brazilian banking efficiency, Innovar, vol.24 no.53, pg. 23-39, Bogota July/Sept 20114. Retrieved from: http://dx.doi.org/10.15446/innovar.v24n53.43772; Accessed on December 27, 2014

Yilmaz A.,A., (2013) Department of Management Bahcesehir University, Istanul, Bank Efficiency Analysis in Turkish Banking System, Published by: WEI International Academic Conference Proceedings, January 14-16, 2013, Antalia, Turkey. E-mail: ayse.yilmaz@bahcesehir.edu.tr; Retrieved From: http://www.westeastinstitute.com; Accessed on: December 28, 2014.

Zeitun, R., \& Benjollun, H., (2012), The efficiency of Banks and Financial Crisis in a Developing Economy: the case of JordanVol.4, No.2, Summer 2012, Pg.28-60. Published by: International Review of Accounting, Banking \& Finance,IRABF @ 2012 
